\title{
The Biology of Balanus balanoides. V. Distribution in the Plymouth Area.
}

\author{
By \\ Hilary B, Moore, Ph,D., \\ Marine Biological Laboratory, Plymouth.
}

With 6 Figures in the Text.

Previous papers in this series (Moore, 1934, $1935 \mathrm{a}$ and b) have described the biology of Balanus balanoides in the Isle of Man. There it is always living in water which is clean, non-estuarine, and not carrying any great quantity of detrital matter in suspension. Further, with the exception of Verruca stromia which occupies rather a different habitat, and of isolated individuals of other species, it is the only species of barnacle found on the Manx shores.

Plymouth, on the other hand, lies in an intermediate position between the region to the west and south where Chthamalus stellatus predominates, and that to the east and north where B. balanoides does (Fischer-Piette, 1933). In the intermediate area, Chthamalus is more abundant in waveexposed situations, while Balanus takes its place in more sheltered places. In addition to this, the rivers which discharge into Plymouth Sound carry with them a large quantity of suspended matter, which, together with the somewhat lowered salinity, give very different conditions from those observed in the Isle of Man. The following five localities were studied (Fig. 1).

Amory Bight, slightly east of Rame Head. Facing south-east, this situation is fully exposed to the open sea from south-west to east. The substratum is Dartmouth Slate (Lower old red sandstone). Owing to bad weather this locality was not very adequately worked.

Misery Point, on the south side of the River Yealm, facing north-east, and completely closed in from the open sea, though close to the mouth of the river. There is a tidal stream of up to $1 \frac{3}{4}$ knots on the flood tide, and $2 \frac{1}{4}$ on the ebb. Though carrying some suspended matter, the water is very much clearer than that in Plymouth Sound. The substratum is again Dartmouth Slate, and drops onto muddy gravel at low water.

Drake's Island. The part worked was on the north side, completely sheltered from the open sea, but subject to some wave action when the wind is in the north or east. There is a tidal stream of up to $1 \frac{1}{4}$ knots 
past the island, and a good deal of suspended matter in the water. The substratum is volcanic rock (upper and middle Devonian).

Tinside, immediately below the Laboratory. Facing south, this is largely sheltered from the open sea by the Breakwater, but as this is two miles away, the rocks are subjected to considerable wave action when

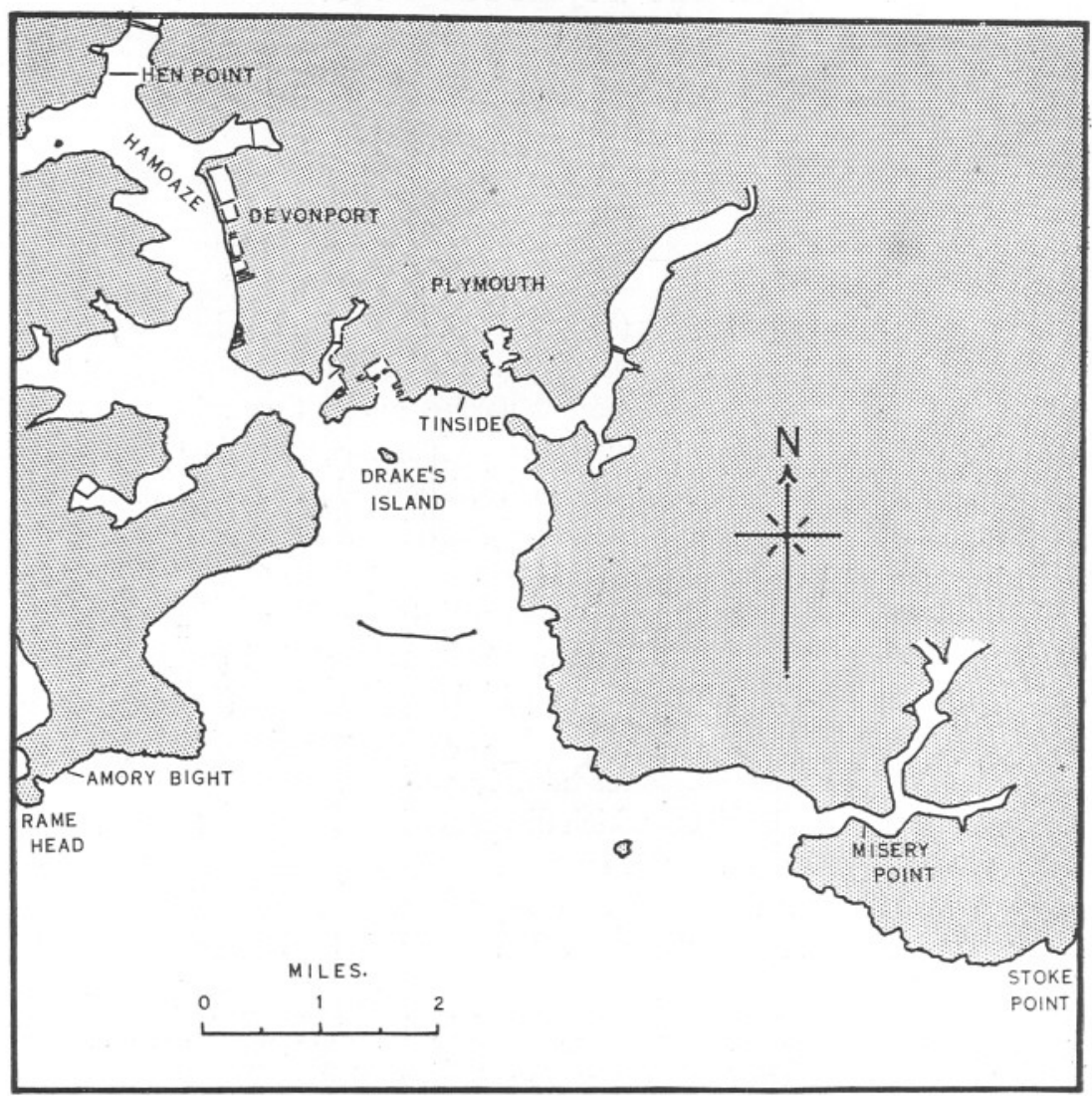

Fic. 1.-Map of the Plymouth area.

the wind is in the south. There is more sediment in the water than at Drake's Island. The substratum is limestone.

Hen Point in the Hamoaze. Facing east-south-east, this shore is completely cut off from the sea, though receiving a little wave action with a southerly wind. There is a one knot tide past the point, and the water contains a very large amount of material in suspension and a very rich diatom plankton. The substratum is volcanic rock, dropping to muddy gravel at low water.

No great accuracy is claimed for the levels. Those at Tinside were fixed 
by reference to known levels on the new swimming pool, and so are accurate to one or two inches. Those on Drake's Island were taken from water level on a very calm day, and compared simultaneously with water level at Tinside, so these also are fairly accurate. At the other three localities no local levels were available, so it was necessary here also to compare with the level of low water on a very calm day, measuring the level simultaneously at Tinside. This undoubtedly introduces an error, though it should not be great, but the present paper is concerned more with numbers and sizes of barnacles than with their absolute levels.

A number of levels were worked at each locality, their heights being determined either with a tape or with a dumpy level. A number of counts, usually between five and fifteen, were made at each level, on an area of either $100 \mathrm{~cm}^{2}$, or $25 \mathrm{~cm}^{2}$, according to the density of the population. Tissue weights were obtained by removing a representative series of barnacles from the rock, decalcifying them, and drying the tissues at $100^{\circ} \mathrm{C}$ (see Moore, 1935 a, p. 264). The various species present were distinguished, as described below, and in addition the first year and older barnacles were kept separate. The counts were made in July-August, 1934, and the first year groups present were those of 1934 in the case of B. balanoides and 1933 in the case of Chthamalus which has a later breeding season. As many of the characters by which the various species of barnacles can be separated are only apparent after dissection, the following notes are given to indicate the characters by which they may most readily be separated in situ.

Verruca strœmia. This species is restricted to low water, and occurs chiefly under stones, a habitat not really included in the present survey. It is easily recognised by the assymetry of the shell, and the striking interlocking folds of the suture between the two large plates of the wall.

Balanus perforatus. This also is readily distinguished by its large size, purplish-grey colour, thick and frequently perforated walls, curved in profile, and by the small size of its aperture. When removed from the rock, the basis is seen to be very thick and perforated by large canals.

$B$. crenatus. This species is extremely difficult to distinguish with certainty from $B$. balanoides without removing it from the rock. As it does not usually occur in numbers above low water, the difficulty does not often arise. Occasionally, however, we have taken it as high as half-tide level. When removed from the rock it is readily distinguished by the fact that it has a thin calcareous basis, while $B$. balanoides has only a membranous one. In situ it may sometimes be distinguished by its whiter shell, since it does not seem to become infected with boring algæ as $B$. balanoides does. The fluting of the walls is often less pronounced, and the apices of the plates sharper. These differences which are sometimes clear enough to allow population counts to be made in situ, after a 
certain amount of practice, can only be trusted when a sufficient number have been checked by removal from their attachment.

B. balanoides and Chthamalus stellatus (Figs. 2 and 3). These are the two really abundant species on the shore in the Plymouth area, and with practice all but very corroded specimens can be distinguished with certainty. In $B$. balanoides the rostral plate of the wall overlaps the two plates on either side, and thus appears to be wide, while in Chthamalus it is overlapped by them and appears to be only about half the width.

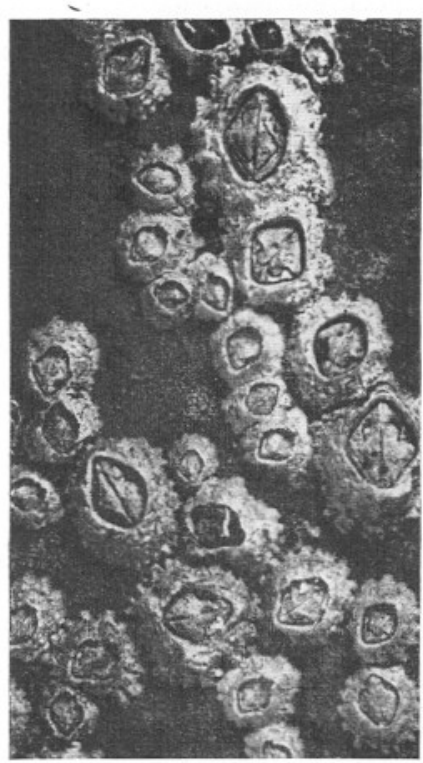

Fig. 2.-B. balanoides $\times 2$.

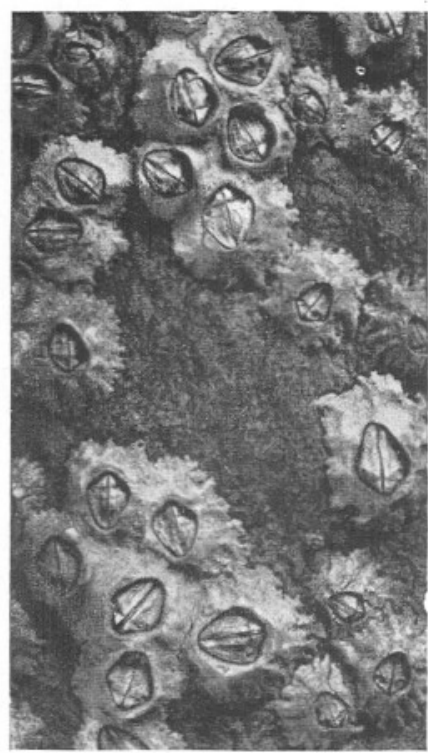

Fig. 3.-Chthamalus stellatus $\times 2$.

These two photographs are of abraded specimens such as are usually found on the shore, and are intended to illustrate the points on which such imperfect specimens may be distinguished.

This character is, however, usually rendered quite useless by the high degree of corrosion of the shell of Chthamalus, this corrosion itself being a character helping in distinguishing the species. In the young barnacles, before the shells become infected with algæ, the shell of Balanus is white, while that of Chthamalus is grey. In some localities the older stages also may be separated by a difference in the colour of the shells. The newly settled spat of Chthamalus also are very much smaller than those of Balanus.

The shape of the opercular aperture is usually the best distinguishing character, this, in B. balanoides, being roughly diamond-shaped, with the sides of equal length, while in Chthamalus it is kite-shaped, with unequal 


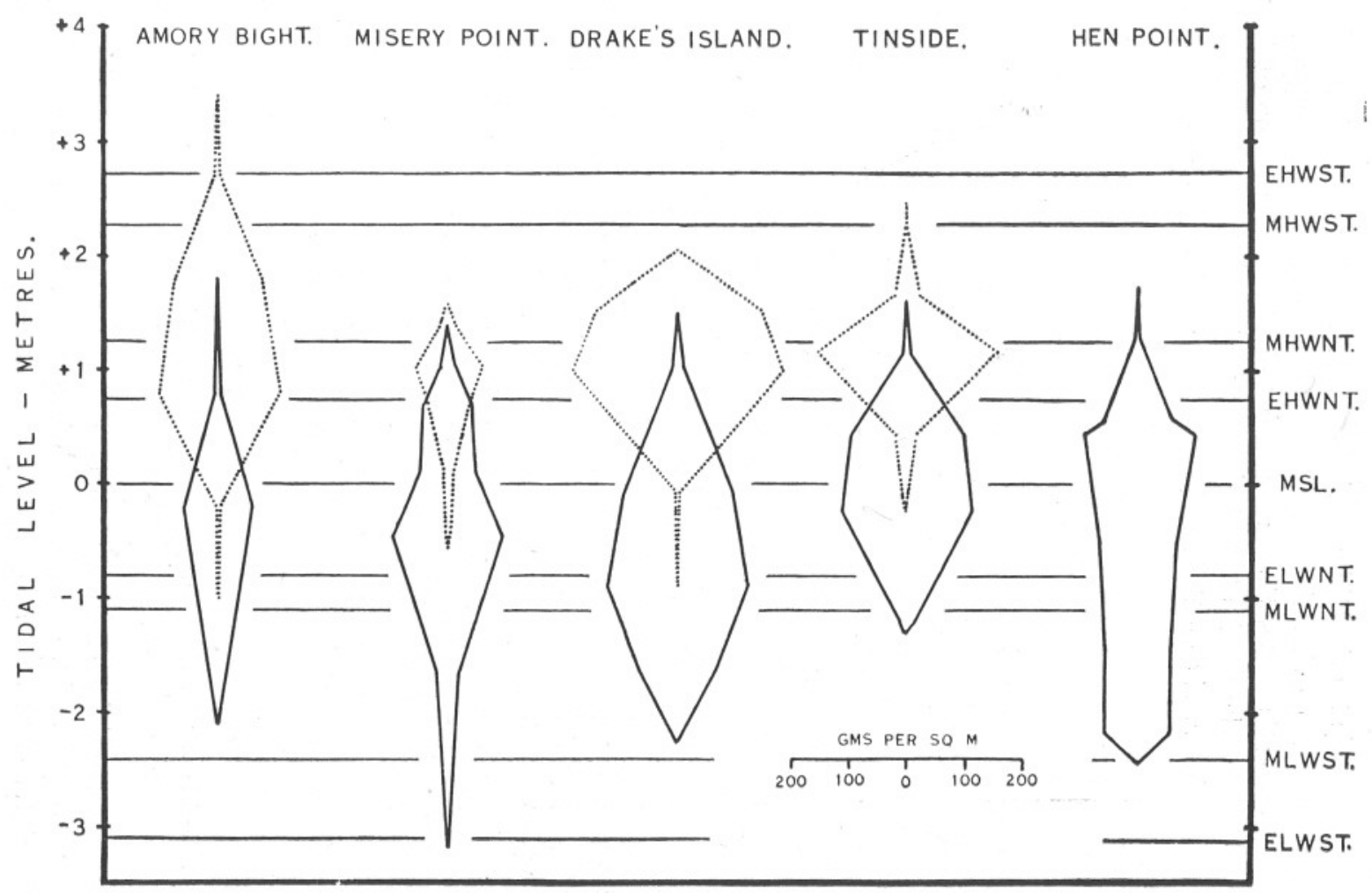

Fig. 4,-Distribution of the two species, Balanus balanoides (whole line) and Chthamalus stellatus (dotted), in relation to tidal level. Amounts of barnacles are in gm. per square metre. 
sides. The opercular plates also fit together more tightly in Chthamalus than in Balanus.

It is known that, other things being equal, $B$. balanoides tends to grow more quickly in moving than in still water, and it has been suggested (Moore, 1935 b) that this effect is the result of the greater amount of food brought within the reach of the barnacle by the moving water. In the same paper it was shown that, while young barnacles grew most rapidly

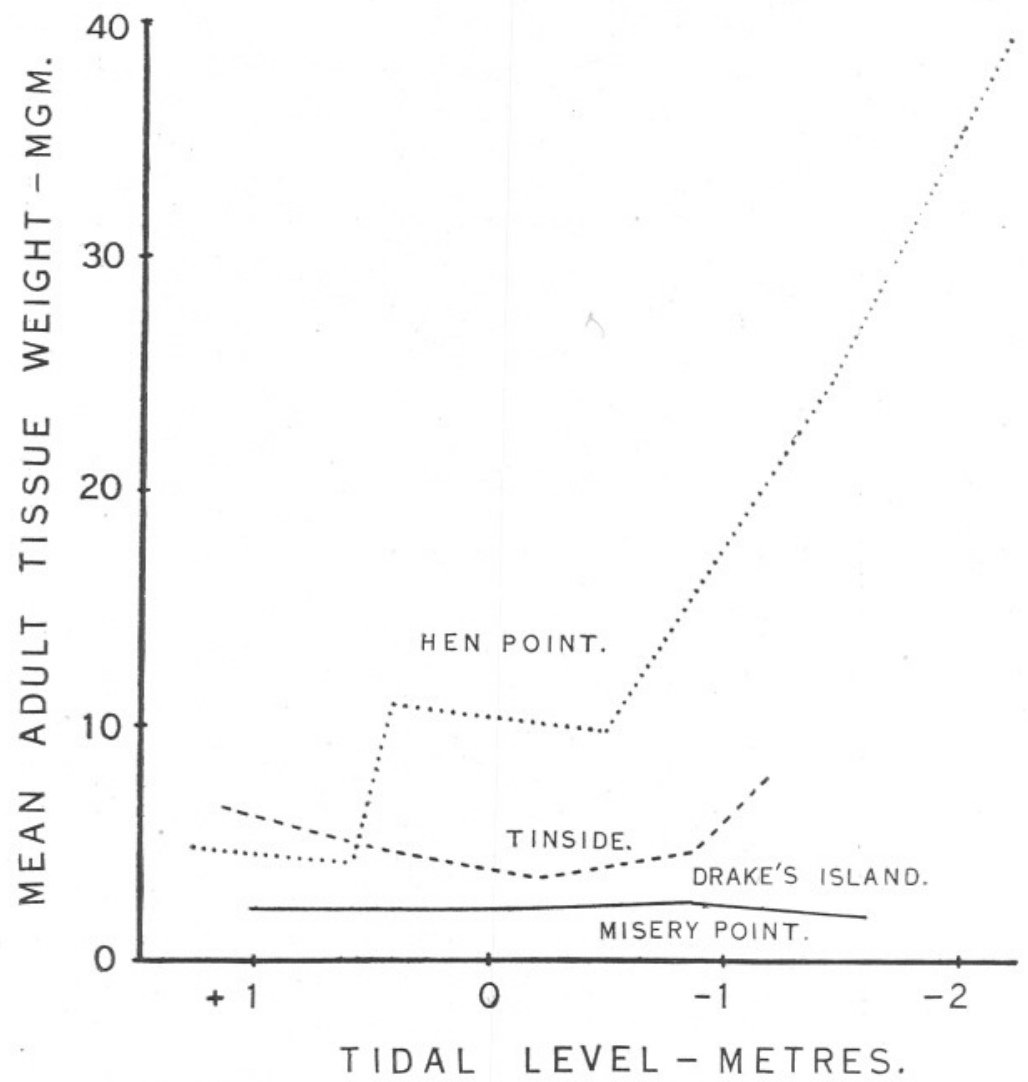

Fig. 5.-The relation of the mean tissue weight of adult $B$. balanoides to tidal level at the various localities.

at low water, with increasing age the optimum level for growth moved up the shore to the highest level at which they occur. The only exception to this statement was that of a very wave-exposed locality where the optimum level remained permanently at low water at all ages.

Figure 4 shows the distribution of the two species, $B$. balanoides and Chthamalus stellatus in the Plymouth area. The localities worked do not form a simple series as did those in the Isle of Man, since here the two factors 
of wave exposure and sediment are both involved. Amory Bight, with a high wave-exposure and very little sediment in the water, compares with the Bradda locality in the Isle of Man. In both cases the lower limit of $B$. balanoides is between mean low water of neaps and spring tides, and the upper limit between mean high water of neaps and springs. In the upper levels at Amory Bight the Balanus is replaced by Chthamalus which reaches up above high water of the highest spring tides, into a zone only reached by splash. It is very hard to understand how an apparently plankton-feeding animal manages to survive in a situation where the only food-bearing sea water which reaches it is the splash during high tide on rough days. Taking Chthamalus and Balanus together, the total numbers of adult barnacles are far greater at Amory Bight-193,000 on a metrewide vertical strip from high to low water-than at Bradda with only 86,300 , but when tissue weight is compared, the conditions are reversed, there being $542 \mathrm{gm}$. at Bradda and only $290 \mathrm{gm}$. at Amory Bight. Of the latter, $107 \mathrm{gm}$. was Balanus and $183 \mathrm{gm}$. Chthamalus (Table VI). At Port Erin, a more sheltered locality in the Isle of Man, there was $106 \mathrm{gm}$. of barnacle tissue per metre strip.

Misery Point which is comparable with Amory Bight in the comparative clearness of the water, differs in its almost complete shelter from wave action, but probably counteracts this to some extent by the strength of the tidal stream past it. With absence of wave-splash, the general zonation is considerably lower here, but, unlike the sheltered localities in the Isle of Man where there was no tidal current, the lower limit does not rise with increased shelter. The amount of barnacles is less at Misery Point than at Amory Bight-199 gm. compared with $290 \mathrm{gm}$.- but this is entirely accounted for by the drop in numbers of Chthamalus in the sheltered locality, the amount of Balanus having actually risen from 107 to $155 \mathrm{gm}$.

The other three stations, Hen Point, Tinside and Drake's Island, form a series with a decreasing amount of sediment in the water, complicated by the increase in amount of wave action in the latter two. In all three there is a slight tidal current.

At Drake's Island B. balanoides extends from about mean low water of spring tides to mean high water of neaps, and Chthamalus up to about mean high water of spring tides, the levels here being somewhat raised by the splash. Below low water of spring tides the growth of algæ, ete. both here and at Tinside is too great to allow the survival of this species. Both the total weight of barnacles and the mean individual weight of the adult barnacles are higher than at Misery Point (Figs. 4 and 5). On Drake's Island B. balanoides and Chthamalus are represented in almost equal quantities. At Tinside, with about the same wave exposure, and slightly greater amount of sediment in the water, the quantities of both 
species are less, especially Chthamalus, but the mean weight of the adult Balanus is considerably greater, especially at low water (Fig. 5). Finally, at Hen Point, where conditions are considerably more estuarine, and the water carries a large amount of matter in suspension, Chthamalus is completely absent, and $B$. balanoides present only in much smaller numbers. But here the growth of the Balanus is so enormously greater than at Tinside (again most marked at low water) that the total weight of

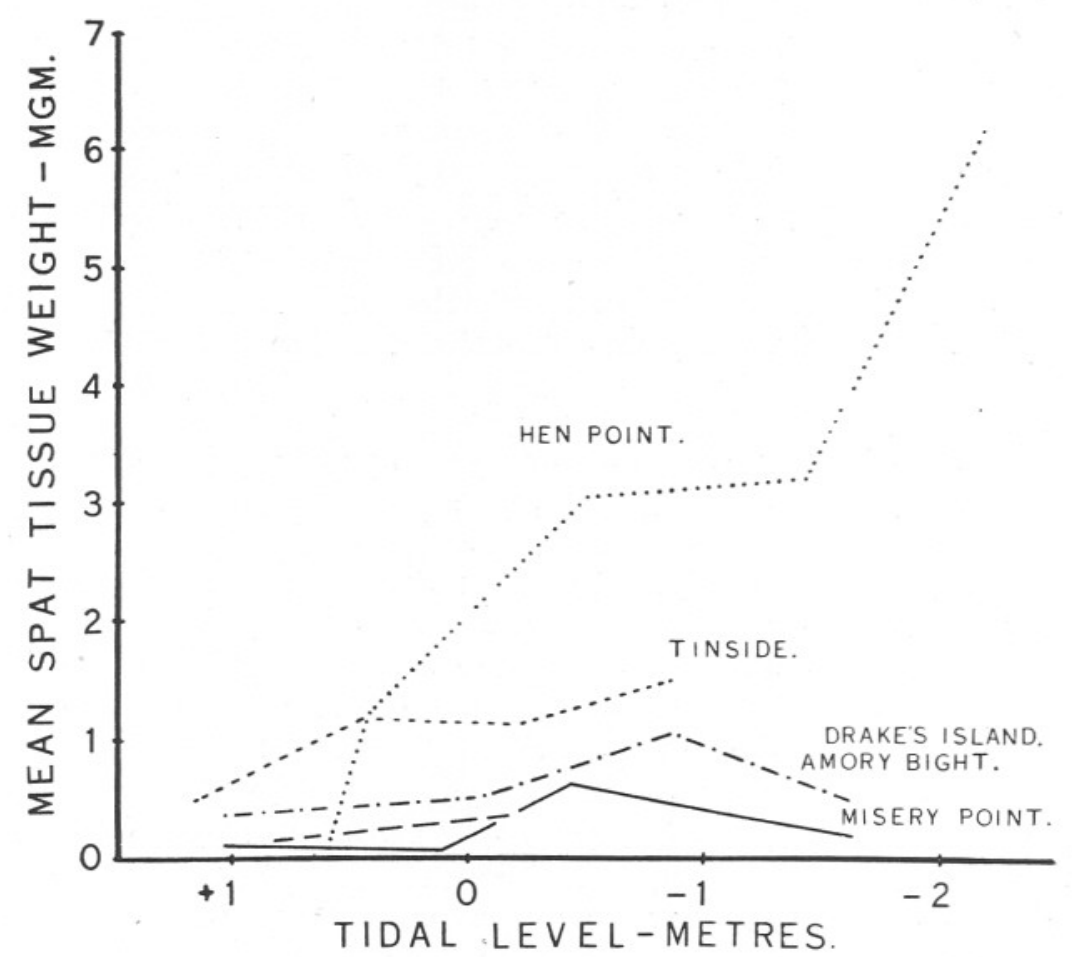

FIG. 6.-The relation of the mean tissue weight of $B$. balanoides spat to tidal level at the various localities.

barnacles is but little less. It seems as if, in these conditions, the spat have considerable difficulty in attaching to the muddy, slimy rocks, but that once attached, food is very abundant and growth correspondingly rapid. In addition they are safe from the attack of the Dog-whelk (Nucella lapillus) which does not penetrate into such estuarine waters.

The mean size of the adult population is not necessarily an index of the rate of growth unless the length of life is the same on the different grounds, which it probably is not. If, however, we can assume that the settlement of the spat takes place at approximately the same time on the different grounds, and there is no reason to think that it does not, then the mean 
size of the one year group whose age is definitely known, namely, the first year group, can be taken as a safe index of growth rate.

The settlement of the spat takes place at Port Erin in April-May, and probably at about the same time at Plymouth. At Port Erin the maximum growth rate of the spat was observed at low water at first, but moving progressively upwards on the shore with increasing age. With very high wave exposure the optimum level remained at low water.

In Figure 6 are shown the mean weights of the first year Balanus spat in July-August at various levels at the different Plymouth stations. At Amory Bight sufficient samples were not taken to show definite results. At both Misery Point and Drake's Island the level for optimum growth had moved up during the three months since settlement, from low water towards mean sea level, and the general level of growth at Drake's Island was about twice that at Misery Point. At Tinside the rate of growth was considerably higher again, and here the optimum level for growth had remained at low water. While the same was true at Hen Point, here the growth rate was enormously higher, the rate at low water being over thirty times that at Misery Point.

In general, then, conditions at Amory Bight and Misery Point are quite comparable with those observed in the Isle of Man, and show similar distributions and quantities of barnacles except for the inclusion of Chthamalus stellatus which does not occur in the Isle of Man. At the other three localities we are dealing with conditions where the great quantity of food material in the water to a large extent outweighs other environmental factors. The effect of this is to reduce the numbers of Balanus present while very greatly increasing their growth rate. And further, this increase is most marked at low water. Since the same effect of increased growth rate was observed to occur at high degrees of wave exposure in the Isle of Man, and particularly at low water, this would seem to support the suggestion already made (Moore, 1935 b, p. 288) that the beneficial effect of water movement on $B$. balanoides was due to the greater quantity of food material which it brought within the barnacle's reach.

\section{SUMMARY.}

1. The barnacles at five localities in the Plymouth area were examined as a check on the general application of observations made previously in the Isle of Man.

2. The numbers and weights per square metre, and the mean individual weights, are given for a series of tidal levels for each locality.

3. The two "clean-water" localities agree substantially with the Isle of Man, except for the presence here of Chthamalus stellatus. 
4. At the three localities where the water is rich in suspended matter first Chthamalus and then Balanus decreases progressively in numbers, but the latter increases very greatly in size, especially at low water.

5. The increased growth rate at low water, where food is abundant, is compared with the similar effect observed in wave-exposed conditions in the Isle of Man.

\section{REFERENCES.}

Fischer-Piette, E. 1933. Sur la Répartition du Ciripède Balanus balanoides le long des Cotes Françaises et Anglaises de la Manche. Assoc. Franç. p. Avanc. des Sciences, Chambéry, pp. 476-480.

Moore, H. B. 1934. The Biology of Balanus balanoides. I. Growth Rate and its Relation to Size, Season and Tidal Level. Journ. Mar. Biol. Assoc., N.S., Vol. XIX, No. 2, pp. 851-868.

- 1935 a. Idem. III. The Soft Parts. Ibid. Vol. XX, No. 2, pp. 263-277.

— 1935 b. Idem. IV. Relation to Environmental Factors. Ibid., pp. 279-307. 


\section{TABLE I.}

Distribution of Barnacles at Amory Bight, August 1st, 1934.

Numbers in brackets are approximate only. Levels (in metres) refer to mean sea level throughout. Weights per sq. m. are in gm.; mean individual weights are in mgm.; volumes are in $\mathrm{mm}^{3}$. B. bal.=Balanus balanoides. Chth. =Chthamalus stellatus .

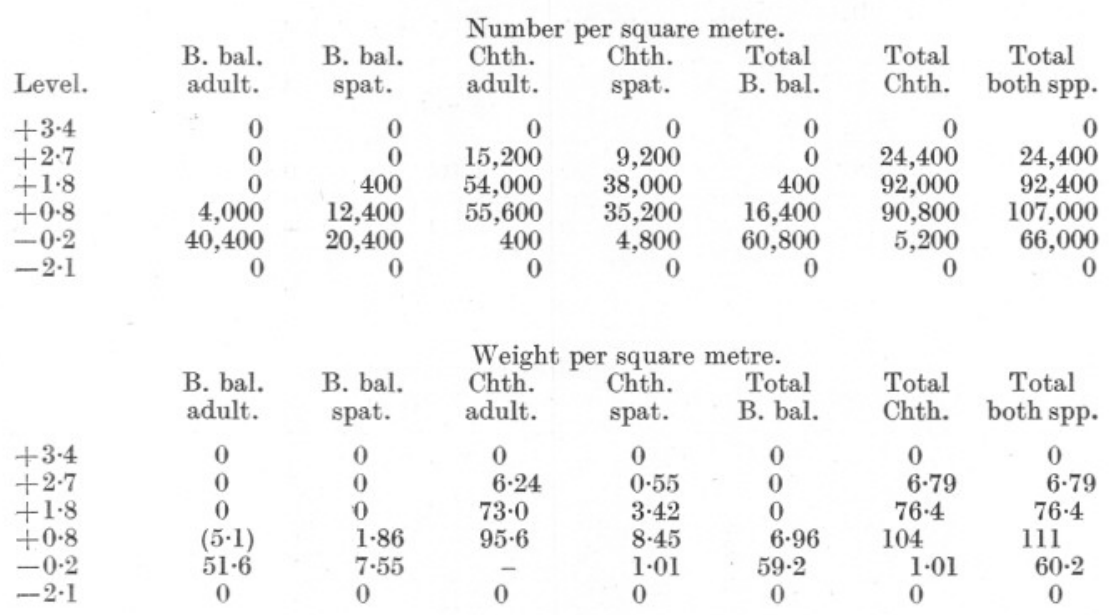

\begin{tabular}{lcclcc}
\multicolumn{3}{c}{ Mean individual weight. } & \multicolumn{2}{c}{ Spat mean volumes. } \\
$\begin{array}{c}\text { B. bal. } \\
\text { adult. }\end{array}$ & $\begin{array}{c}\text { B. bal. } \\
\text { spat. }\end{array}$ & $\begin{array}{c}\text { Chth. } \\
\text { adult. }\end{array}$ & $\begin{array}{c}\text { Chth. } \\
\text { spat. }\end{array}$ & B. bal. & Chth. \\
- & - & - & - & - & - \\
- & - & $0 \cdot 41$ & $0 \cdot 06$ & - & $0 \cdot 43$ \\
- & - & $1 \cdot 37$ & $0 \cdot 09$ & - & $0 \cdot 59$ \\
- & $0 \cdot 15$ & $1 \cdot 72$ & $0 \cdot 24$ & $1 \cdot 52$ & $1 \cdot 71$ \\
$1 \cdot 28$ & $0 \cdot 37$ & - & $0 \cdot 21$ & $3 \cdot 10$ & $1 \cdot 66$ \\
- & - & - & - & - & -
\end{tabular}




\section{TABLE II.}

Distribution of Barnacles at Misery Point, July 30th, 1934.

Figures as in Table I.

\begin{tabular}{rrrrrrrr} 
& \multicolumn{7}{c}{ Number per square metre. } \\
Level. & $\begin{array}{r}\text { B. bal. } \\
\text { adult. }\end{array}$ & $\begin{array}{c}\text { B. bal. } \\
\text { spat. }\end{array}$ & $\begin{array}{r}\text { Chth. } \\
\text { adult. }\end{array}$ & $\begin{array}{r}\text { Chth. } \\
\text { spat. }\end{array}$ & $\begin{array}{r}\text { Total } \\
\text { B. bal. }\end{array}$ & $\begin{array}{r}\text { Total } \\
\text { Chth. }\end{array}$ & $\begin{array}{c}\text { Total } \\
\text { both spp. }\end{array}$ \\
$+1 \cdot 59$ & 0 & 0 & 0 & 0 & 0 & 0 & 0 \\
$+1 \cdot 39$ & 0 & 0 & 7,700 & 1,900 & 0 & 9,600 & 9,600 \\
$+1 \cdot 02$ & 10,000 & 2,800 & 54,400 & 15,600 & 12,800 & 70,000 & 82,800 \\
$+0 \cdot 70$ & 34,000 & 7,200 & 26,800 & 8,000 & 41,200 & 34,800 & 76,000 \\
$+0 \cdot 11$ & 52,800 & 28,000 & 7,200 & 4,400 & 80,800 & 11,600 & 92,400 \\
$-0 \cdot 46$ & 32,800 & 59,600 & 2,400 & 3,600 & 92,400 & 6,000 & 98,400 \\
$-0 \cdot 56$ & - & - & 0 & 0 & - & 0 & - \\
$-1 \cdot 66$ & 3,600 & 57,200 & 0 & 0 & 60,800 & 0 & 60,800 \\
$-3 \cdot 16$ & 0 & 0 & 0 & 0 & 0 & 0 & 0
\end{tabular}

$+1 \cdot 59$

$+1 \cdot 39$

$+1 \cdot 02$

$+0 \cdot 70$

$+0 \cdot 11$

$-0.46$

$-0.56$

$-1 \cdot 66$

$-3 \cdot 16$

Weight per square metre.

B. bal. B. bal. Chth. Chth. Total Total Total adult. spat. adult. spat. B. bal. Chth. both spp.

$\begin{array}{rrrrrrr}0 & 0 & 0 & 0 & 0 & 0 & 0 \\ 0 & 0 & 10 \cdot 3 & 2 \cdot 55 & 0 & 12 \cdot 9 & 12 \cdot 0 \\ (11 \cdot 7) & 0 \cdot 28 & 56 \cdot 0 & 1 \cdot 72 & (12 \cdot 0) & 57 \cdot 7 & (69 \cdot 7) \\ 39 \cdot 8 & 0 \cdot 58 & 31 \cdot 1 & 0 \cdot 96 & 40 \cdot 4 & 32 \cdot 1 & 72 \cdot 5 \\ 46 \cdot 0 & 2 \cdot 24 & 6 \cdot 60 & 0 \cdot 66 & 48 \cdot 2 & 7 \cdot 26 & 55 \cdot 5 \\ 53 \cdot 8 & 38 \cdot 1 & 2 \cdot 88 & 0 \cdot 47 & 91 \cdot 9 & 3 \cdot 35 & 95 \cdot 3 \\ - & - & 0 & 0 & - & 0 & - \\ 5 \cdot 65 & 11 \cdot 4 & 0 & 0 & 17 \cdot 1 & 0 & 17 \cdot 1 \\ 0 & 0 & 0 & 0 & 0 & 0 & 0\end{array}$

Mean individual weight.

B. bal. B. bal. Chth. adult. spat. adult.

$+1 \cdot 59$

$+1 \cdot 39$

$+1 \cdot 02$

$+0.70$

$+0.11$

$-0 \cdot 46$

$-0.56$

$-1 \cdot 66$

$-3 \cdot 16$
$-$

$-$

$1 \cdot 17$

$0 \cdot 87$

1.64

$\overline{1} \cdot 57$

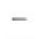

$0 \cdot 10$

0.08

0.08

$0 \cdot 64$

$\overline{0} \cdot 20$
Spat mean volumes.

Chth.

spat.

B. bal. Chth.

-
$1 \cdot 34$
$1 \cdot 03$
$1 \cdot 16$
$0 \cdot 93$
$1 \cdot 20$
-
-

-
-
$0 \cdot 11$
$0 \cdot 12$
$0 \cdot 15$
$0 \cdot 13$
-
-

-

$0 \cdot 64$

$0 \cdot 83$

$1 \cdot 14$

$1 \cdot 32$

$3.91 \quad-$




\section{TABLE III.}

Distribution of Barnacles at Drake's Island, July 27th, 1934.

Figures as in Table I.

\begin{tabular}{|c|c|c|c|c|c|c|c|}
\hline \multirow[b]{2}{*}{ Level. } & \multirow[b]{2}{*}{$\begin{array}{l}\text { B. bal. } \\
\text { adult. }\end{array}$} & \multirow[b]{2}{*}{$\begin{array}{l}\text { B. bal. } \\
\text { spat. }\end{array}$} & \multicolumn{3}{|c|}{ Number per square metre. } & \multirow[b]{2}{*}{$\begin{array}{l}\text { Total } \\
\text { Chth. }\end{array}$} & \multirow[b]{2}{*}{$\begin{array}{c}\text { Total } \\
\text { both spp. }\end{array}$} \\
\hline & & & $\begin{array}{l}\text { Chth. } \\
\text { adult. }\end{array}$ & $\begin{array}{l}\text { Chth. } \\
\text { spat. }\end{array}$ & $\begin{array}{l}\text { Total } \\
\text { B. bal. }\end{array}$ & & \\
\hline$+2 \cdot 04$ & 0 & 0 & 0 & 0 & 0 & 0 & \\
\hline$+1 \cdot$ & 0 & 0 & 20,800 & 0 & 0 & 20,800 & 20,800 \\
\hline+1.51 & 0 & 0 & 46,400 & 4,800 & 0 & 51,200 & 51,200 \\
\hline$+1 \cdot 01$ & 3,200 & 7,600 & 61,600 & 13,600 & 10,800 & 75,200 & 86,000 \\
\hline$-0 \cdot 09$ & 31,600 & 42,400 & 0 & 1,200 & 74,000 & 1,200 & 75,200 \\
\hline-0.89 & 19,600 & 67,600 & 0 & 0 & 87,200 & 0 & $* 87,20$ \\
\hline$-1 \cdot 64$ & 20,800 & 44,000 & 0 & 0 & 64,800 & 0 & 64,80 \\
\hline$-2 \cdot 24$ & 0 & 0 & 0 & 0 & 0 & 0 & \\
\hline
\end{tabular}

B. bal. B, bal. Chth. Chthe per square metre. adult. spat. adult. spat. B. bal. Chth. both spp.

0
0
0
$7 \cdot 04$
$75 \cdot 2$
$51 \cdot 9$
$44 \cdot 3$
0

$\begin{array}{lc}0 & 0 \\ 0 & 65 \cdot 1 \\ 0 & 145 \\ 2 \cdot 73 & 181 \\ 22 \cdot 9 & 0 \\ 71 \cdot 6 & 0 \\ 22 \cdot 5 & 0 \\ 0 & 0\end{array}$

0
0
$1 \cdot 30$
$3 \cdot 13$
$0 \cdot 09$
0
0
0

0
0
0
$9 \cdot 77$
$98 \cdot 1$
123
$66 \cdot 7$

$\begin{array}{cc}0 & 0 \\ 65 \cdot 1 & 65 \cdot 1 \\ 146 & 146 \\ 184 & 194 \\ 0 \cdot 09 & 98 \cdot 2 \\ 0 & 123 \dagger \\ 0 & 66 \cdot 7 \\ 0 & 0\end{array}$

Mean individual weight. B. bal. B. bal. Chth. adult. spat. adult.

\begin{tabular}{|c|c|c|c|c|c|c|}
\hline$+2 \cdot 04$ & - & - & - & - & - & - \\
\hline+1.81 & - & - & $3 \cdot 13$ & - & - & - \\
\hline+1.51 & - & - & $3 \cdot 13$ & $0 \cdot 27$ & - & $1 \cdot 40$ \\
\hline+1.01 & $2 \cdot 20$ & $0 \cdot 36$ & $2 \cdot 94$ & $0 \cdot 23$ & $2 \cdot 96$ & $1 \cdot 14$ \\
\hline-0.09 & $2 \cdot 38$ & 0.54 & - & 0.08 & $3 \cdot 91$ & $1 \cdot 24$ \\
\hline-0.89 & $2 \cdot 65$ & $1 \cdot 06$ & - & - & $5 \cdot 55$ & - \\
\hline$-1 \cdot 64$ & $2 \cdot 13$ & 0.51 & - & - & $3 \cdot 56$ & - \\
\hline$-2 \cdot 24$ & - & - & - & - & - & - \\
\hline
\end{tabular}

Spat mean volumes.

Chth. spat. B. bal. Chth.

* Together with $400 \mathrm{~B}$. perforatus per square metre, with a mean weight of $69 \cdot 9 \mathrm{mgm}$.

$\uparrow$ Together with $28.0 \mathrm{gm}$. of B. perforatus. 


\section{TABLE IV.}

Distribution of Barnacles at Tinside, July 7-14th, 1934.

Figures as in Table I.

\begin{tabular}{|c|c|c|c|c|c|c|c|}
\hline & & & Numbe & r squar & etre. & & \\
\hline Level. & $\begin{array}{l}\text { B. bal. } \\
\text { adult. }\end{array}$ & $\begin{array}{c}\text { B. bal. } \\
\text { spat. }\end{array}$ & $\begin{array}{l}\text { Chth. } \\
\text { adult. }\end{array}$ & $\begin{array}{l}\text { Chth. } \\
\text { spat. }\end{array}$ & $\begin{array}{l}\text { Total } \\
\text { B. bal. }\end{array}$ & $\begin{array}{l}\text { Total } \\
\text { Chth. }\end{array}$ & $\begin{array}{c}\text { Total } \\
\text { both spp. }\end{array}$ \\
\hline+2.48 & 0 & 0 & 0 & 0 & 0 & 0 & 0 \\
\hline$+2 \cdot 28$ & 0 & 0 & 500 & 0 & 0 & 500 & 500 \\
\hline$+1 \cdot 64$ & 0 & 0 & 12,800 & 5,200 & 0 & 18,000 & 18,000 \\
\hline$+1 \cdot 14$ & 1,600 & 800 & 31,200 & 7,200 & 2,400 & 38,400 & 40,800 \\
\hline+0.43 & 12,000 & 32,000 & 10,000 & 2,400 & 44,000 & 12,400 & 56,400 \\
\hline-0.24 & 21,200 & 28,400 & 0 & 0 & 49,600 & 0 & 49,600 \\
\hline-0.89 & 8,000 & 48,000 & 0 & 0 & 56,400 & 0 & 56,400 \\
\hline$-1 \cdot 21$ & 1,200 & 0 & 0 & 0 & 1,200 & 0 & 1,200 \\
\hline$-1 \cdot 3$ & 0 & 0 & 0 & 0 & 0 & 0 & \\
\hline
\end{tabular}

B. bal B. Weight per square metre.

$+2 \cdot 48$

adult. spat.

B. bal. Chth. both spp.

$+2 \cdot 28$

$+1 \cdot 64$

$+1 \cdot 14$

$+0 \cdot 43$

$-0 \cdot 24$

$-0 \cdot 89$

$-1 \cdot 21$

$-1 \cdot 31$

0
0
0
$\quad 6 \cdot 37$
$56 \cdot 5$
$76 \cdot 7$
$38 \cdot 3$
$9 \cdot 71$
0

$\begin{array}{lc}0 & 0 \\ 0 & 0 \cdot 94 \\ 0 & 17 \cdot 3 \\ 0 \cdot 40 & 154 \\ 38 \cdot 1 & 17 \cdot 3 \\ 32 \cdot 4 & 0 \\ 7 \cdot 26 & 0 \\ 0 & 0 \\ 0 & 0\end{array}$

0
0
$2 \cdot 90$
$2 \cdot 33$
$1 \cdot 46$
0
0
0
0

0
0
0
$6 \cdot 77$
$94 \cdot 6$
109
$45 \cdot 6$
$9 \cdot 71$

$\begin{array}{cc}0 & 0 \\ 0 \cdot 94 & 0 \cdot 94 \\ 20 \cdot 2 & 20 \cdot 2 \\ 156 & 163 \\ 18 \cdot 8 & 112 \\ 0 & 109 \\ 0 & 45 \cdot 6 \\ 0 & 9 \cdot 71 \\ 0 & 0\end{array}$

B. bal.

Mean individual weight.

Chth.

Spat mean volumes.

$+2 \cdot 48$
$+2 \cdot 28$
$+1 \cdot 6$
$+1 \cdot 1$
$+0 \cdot 43$
$-0 \cdot 2$
$-0 \cdot 8$
$-1 \cdot 2$
$-1 \cdot 3$ spat. adult.

spat.

B. bal.

Chth.

$\begin{array}{llllll}- & - & - & - & - & - \\ - & - & 1 \cdot 88 & - & - & 0 \cdot 54 \\ - & - & 1 \cdot 35 & 0 \cdot 56 & - & 0 \cdot 73 \\ 6 \cdot 37 & 0 \cdot 50 & 4 \cdot 94 & 0 \cdot 31 & 5 \cdot 93 & 2 \cdot 28 \\ 4 \cdot 71 & 1 \cdot 19 & 1 \cdot 73 & 0 \cdot 61 & 10 \cdot 4 & 3 \cdot 88 \\ 3 \cdot 62 & 1 \cdot 14 & - & - & 10 \cdot 5 & - \\ 4 \cdot 79 & 1.50 & - & - & 8 \cdot 96 & - \\ 8 \cdot 09 & - & - & - & 7 \cdot 52 & - \\ - & - & - & - & - & -\end{array}$




\section{TABLE V.}

Distribution of Barnacles at Hen Point, July 16-17th, 1934.

Figures as in Table I. B. cren.=Balanus crenatus.

\begin{tabular}{|c|c|c|c|c|c|c|c|}
\hline & \multicolumn{7}{|c|}{ Number per square metre. } \\
\hline & $\begin{array}{l}\text { B. bal. } \\
\text { adult. }\end{array}$ & $\begin{array}{c}\text { B. bal. } \\
\text { spat. }\end{array}$ & $\begin{array}{l}\text { B. cren. } \\
\text { adult. }\end{array}$ & $\begin{array}{l}\text { B. cren. } \\
\text { spat. }\end{array}$ & $\begin{array}{l}\text { Total } \\
\text { B. bal. }\end{array}$ & $\begin{array}{c}\text { Total } \\
\text { B. cren. }\end{array}$ & $\begin{array}{c}\text { Total } \\
\text { both spp. }\end{array}$ \\
\hline$+1 \cdot 72$ & 0 & 0 & 0 & 0 & 0 & 0 & 0 \\
\hline$+1 \cdot 27$ & 540 & 0 & 0 & 0 & 540 & 0 & 540 \\
\hline+0.57 & 13,200 & 13,600 & 0 & 0 & 26,800 & 0 & 26,800 \\
\hline+0.42 & 7,300 & 11,200 & 0 & 0 & 18,500 & 0 & 18,500 \\
\hline-0.51 & 6,300 & 1,100 & 0 & 0 & 7,400 & 0 & 7,400 \\
\hline$-1 \cdot 43$ & 2,100 & 900 & 30 & 0 & 3,000 & 30 & 3,030 \\
\hline$-2 \cdot 18$ & 1,300 & 200 & 460 & 150 & 1,500 & 610 & 2,100 \\
\hline$-2 \cdot 43$ & 0 & 0 & $?^{*}$ & ?* & 0 & ?* & ?* \\
\hline
\end{tabular}

B, bal. B, bal Weights per square metre.

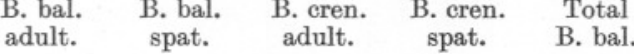

0
0
0
0
0
0
0


TABLE VI.

Amounts of Barnacles on a One Metre Wide Vertical Strip of Shore.

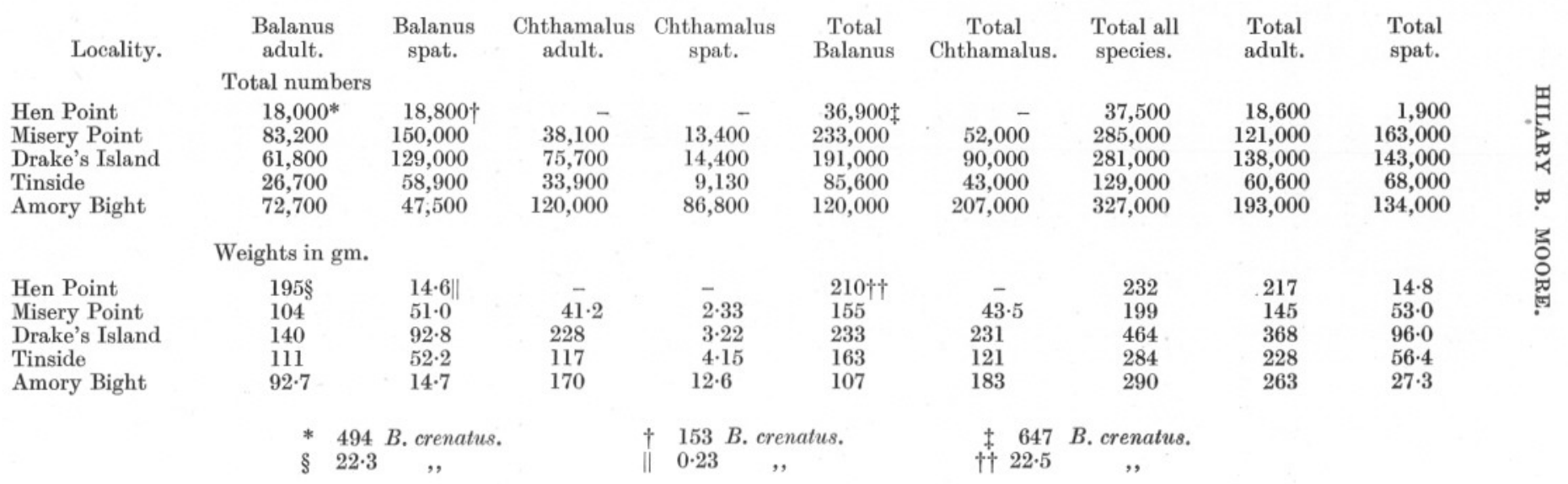

